\title{
INCREASING ADDED VALUE FOR THE NEW CITY OF WALINI THROUGH INFRASTRUCTURE PROJECT DEVELOPMENT
}

\author{
Mohammed Ali Berawi ${ }^{1 *}$, Perdana Miraj ${ }^{2}$, Abdur Rohim Boy Berawi ${ }^{3}$, Revaldo Agdhitya ${ }^{3}$ \\ ${ }^{1}$ Associate Professor, Civil Engineering Department, Faculty of Engineering, University of \\ Indonesia \\ ${ }^{2}$ Department of Civil Engineering, Faculty of Engineering, Universitas Pancasila, Jalan Srengseng \\ Sawah, Jagakarsa, Jakarta Selatan 12640, Indonesia \\ ${ }^{3}$ Center for Sustainable Infrastructure Development, Faculty of Engineering, Universitas Indonesia, \\ Kampus UI Depok, Depok 16424, Indonesia
}

(Received: December 2016 / Revised: March 2017 / Accepted: October 2017)

\begin{abstract}
The government of Indonesia continues to promote infrastructure development in various sectors such as road transport, ports, and new railway lines. One of the large infrastructure projects that aims to increase regional and national economic growth is the high-speed rail line linking Jakarta and Bandung. The connecting of these two major cities (Jakarta in the northwest of Java Island and Bandung in the south-west) will significantly contribute to the country's gross domestic product (GDP). As one of the areas that will be connected to the high-speed rail line, Walini has tremendous potential for development. There is the opportunity to develop the new city as a center for agriculture commodities such as tea and rubber, but other city development formats should also be considered, such as business capital, government functions, or IT. The development of Walini requires proper planning and a comprehensive conceptual design which focuses on the vision developed in the initial blueprint. This research aims to conduct a comprehensive study by considering development prospects and regional characteristics, as well as added value to increase competitiveness in terms of infrastructure, technological readiness, and urban development. It will combine approaches from both qualitative perspectives and quantitative investigation, using in-depth interviews and a decision matrix as evaluation tools to select the best alternative for the direction of city planning. This study produces a strategic recommendation for government and other related stakeholders about regional development and urban city planning for Walini as a new IT-based city and technology park.
\end{abstract}

Keywords: Agglomeration; Economic impact; Infrastructure; regional development; spatial planning

\section{INTRODUCTION}

Economic development in a nation requires connectivity between production centers and processing industries. Infrastructure plays a crucial role as a prerequisite for transporting people and goods from one area to another (Berawi \& Susantono, 2012). Its availability not only acts as a connector but also as a booster for local activities and the development of regions (Berawi et al., 2015). Many researchers have identified the correlation between infrastructure and regional development and vice versa (Komarova et al., 2014; Nijkamp, 2016).

*Corresponding author's email: maberawi@eng.ui.ac.id, Tel. +62-21-7270029, Fax. +62-21-7270028

Permalink/DOI: https://doi.org/10.14716/ijtech.v8i6.755 
Although infrastructure is usually developed to accommodate the already existing needs of trade, it may also be built to proactively stimulate trade in a particular area.

As the need to develop infrastructure and urban economic activities in Indonesia has increased significantly in recent years, the government of the country plans to build new railway networks in Java Island, such as the Jakarta-Bandung high-speed railway. The government argues that this is one of the promising projects that is expected to support connectivity for both cities, as well as to encouraging new urban development. The project is planned to stretch $142 \mathrm{~km}$ between four stations, at Halim, Karawang, Walini, and Tegalluar. This project requires substantial funds of approximately Rp 70 trillion (\$5 billion). One of the solutions suggested to attract investment is to develop Walini in West Java province as a transit-oriented development.

However, new cities developed without proper vision and direction may follow the failure of previous cities in which spatial planning was derived only from trade and excluded other aspects of connectivity and the people in the area themselves (Leigh \& Blakely, 2013). The population in another area in Bandung, which acts as the capital of West Java province, should also be taken into account as one contributing factor in developing New Walini, in concert with the structural concept for the city.

Various city development schemes have been designed and implemented over the last three decades: Putrajaya in Malaysia with a centralized-government focus, Singapore as a city of business, Auckland in New Zealand focusing on the agricultural sector, and in California the Silicon Valley area with its ICT and innovation-led economy. Based on these many types of development concept, this research aims to look at the development of the new city of Walini and evaluate the most suitable concept to boost the economic development of the region and substantially contribute to national GDP.

\section{REGIONAL DEVELOPMENT}

Regional development is conducted to achieve the required aspects of a city through growth, equitable expansion and sustainability, with local dimensions related to economic and social considerations. Regional developments acts as extension centers that contribute to local growth and to national competitiveness. In regions of strategic development natural resources, human resources and infrastructure are interconnected and integrated to generate optimal output.

Many scholars and researchers have identified theories and models of regional development including stage ideas, location factors, and sectoral transformation (North, 1955; Birch, 1971; Friedmann, 1986). Various studies also explore not only the linking of rural and urban areas or local-national development but also transforming developing nations into developed countries (Monastiriotis, 2014; Pike et al., 2016).

In this research, four regional developments are selected as benchmarks, namely Putrajaya in Malaysia (a centralized-government city), Singapore (a business city), Auckland in New Zealand (an agriculture city) and the Silicon Valley area of San Francisco (an IT-based city). Putrajaya is a newly developed city that combines government institutions and their related components, such as commercial areas, housing, public facilities, and infrastructure. In total, comprises 4,931 ha of land for development with $6 \%$ allocated to the government district. The city expansion took six to seven years from the planning stage to becoming operational. From 2008 to 2014, the economy and population grew by $2.6 \%$ and $4.05 \%$ respectively (Department of Statistics Malaysia, 2015).

In contrast, Singapore is a leading city-state for business and investment. The central region of Singapore has small amounts of integrated land use for commercial, retail, hotels, office and other building functions. Those areas contribute about $10 \%$ of the total area. Although the city- 
state has one of the highest densities of population in the world, population growth is relatively stable at about $1.74 \%$ a year (Department of Statistics Singapore, 2015). Its economic growth has relied mainly on business and this has proved a successful formula, establishing the city as one of the leading countries in term of GDP per capita in the world.

Auckland is located in the northern part of New Zealand, where the economy mainly depends on agriculture and animal husbandry. Just over three quarters $(77 \%)$ of Auckland's land comprises open spaces, with the rest used for city development. Auckland has had stable economic and population growth over recent years (Statistics New Zealand, 2015).

The Silicon Valley in California is an innovative area in which many ICT companies have placed their headquarters. Silicon Valley's development is linked to Stanford University's role as an "Entrepreneurship University", and is based on the successfully implementation of the "triple helix" concept - a collaboration of industry, government institutions and universities (Etzkowitz, 2011). The area consists of commercial, office, and residential use, while its vast open spaces still offer the potential for development of industry and offices. Despite the population reducing between 2009 and 2015 by about $1.31 \%$, the potential for economic development is enormous (Ooms et al., 2015). As the world becomes more dependent on technology (Berawi, 2017), the concept of technoparks and IT-based cities is one of the likely factors to be applied to Walini project.

\section{METHODOLOGY}

The research methodology of this study follows systematic steps, namely the allocation of points to determining indicators, ranking the alternatives for each indicator and creating a decision matrix. First, secondary data is investigated from journals, books, and other sources (Karim et al., 2007; Berawi \& Woodhead, 2008) about regional development in related cities and areas, such as Putrajaya, Singapore, Auckland, and Silicon Valley. From this literature, five indicators are suggested as research variables: the potential development sector, development cost, period of development, economic growth, and population growth. Then, pairwise comparison is used to accommodate the decision-making process in generating the most suitable city concept for Walini. The pairwise comparison method can be seen in Table 1 .

Table 1 Pairwise comparison sample

\begin{tabular}{|c|c|c|c|c|c|c|}
\hline & B & C & D & Score & Percentage & Description \\
\hline \multirow[t]{5}{*}{$\mathbf{A}$} & B 1 & C 3 & D 1 & 0 & $0.00 \%$ & A \\
\hline & B & C 2 & $\begin{array}{ll}\text { B } & 1\end{array}$ & 2 & $18.18 \%$ & B \\
\hline & & C & C 3 & 8 & $72.73 \%$ & $\mathrm{C}$ \\
\hline & & & D & 1 & $9.09 \%$ & $\mathrm{D}$ \\
\hline & & & & 11 & $100 \%$ & \\
\hline
\end{tabular}

Source: Woodhead and Berawi (2008)

In this example, four indicators will be investigated to determine the highest contributing factor in a project based on the scale of interest: 1: low, 2: moderate, and 3: high. For the second row, $\mathbf{B}$ has more significant impact than $\mathbf{A}$, with a scale of 1 , thus written as $\mathbf{B}(1)$. Then, $\mathbf{C}$ has more significant impact than $\mathbf{A}$ with a scale of 3, thus written as C(3). Last, $\mathbf{D}$ has more significant impact than $\mathbf{A}$ with a scale of 1 , written as $\mathrm{D}(1)$.

The overall score for $\mathbf{A}$ is zero because $\mathbf{B}, \mathbf{C}$, and $\mathbf{D}$ are higher than $\mathbf{A}$. Similar treatment is also conducted for the rest of the row to $\mathbf{D}$. B has a score of 2 both from the first and second rows. $\mathbf{C}$ 
has a score of eight, three (C3) from the first row, two (C2) from the second row and three (C3) from the third row. The percentage score of indicators from Table 1 will be used in the score box in the second row in Table 2 .

Table 2 Determining the weighting score in pairwise comparison

\begin{tabular}{|c|c|c|c|c|c|c|}
\hline Indicator & A & $\mathrm{B}$ & $\mathrm{C}$ & $\mathrm{D}$ & & \\
\hline Score & $X$ & $\mathrm{x}_{2}$ & $\mathrm{x}_{3}$ & $\mathrm{X}_{4}$ & & \\
\hline \multicolumn{5}{|c|}{ City Type } & Total Score & Rank \\
\hline 1 & $\begin{array}{c}\mathrm{J} \\
(\mathrm{xj})\end{array}$ & $\begin{array}{c}\mathrm{j}_{2} \\
\left(\mathrm{x}_{2} \mathrm{j}_{2}\right)\end{array}$ & $\begin{array}{c}\mathrm{j}_{3} \\
\left(\mathrm{x}_{3} \mathrm{j}_{3}\right)\end{array}$ & $\begin{array}{c}\mathrm{j}_{4} \\
\left(\mathrm{x}_{4} \mathrm{j}_{4}\right)\end{array}$ & $(x \mathrm{j})+\left(\mathrm{x}_{2} \mathrm{j}_{2}\right)+\left(\mathrm{x}_{3} \mathrm{j}_{3}\right)+\left(\mathrm{x}_{4} \mathrm{j}_{4}\right)$ & \\
\hline 2 & $\begin{array}{c}\mathrm{Tj} \\
(\mathrm{xtj})\end{array}$ & $\begin{array}{c}\mathrm{tj}_{2} \\
\left(\mathrm{x}_{2} \mathrm{tj}_{2}\right)\end{array}$ & $\begin{array}{c}\mathrm{tj}_{3} \\
\left(\mathrm{x}_{3} \mathrm{tj}_{3}\right)\end{array}$ & $\begin{array}{c}\mathrm{tj}_{4} \\
\left(\mathrm{x}_{4} \mathrm{t}_{4}\right)\end{array}$ & $(x t j)+\left(x_{2} t_{2}\right)+\left(x_{3} \mathrm{tj}_{3}\right)+\left(x_{4} \mathrm{t}_{4}\right)$ & \\
\hline$\ldots$ & & & & & & \\
\hline
\end{tabular}

In Table 2, four types of cities will be used to determine the Walini concept. These consist of an IT-based city, an agriculture city, a centralized-government city, and a business city. The city generates a score for each indicator. This is then multiplied by the score of the indicator before summing up to obtain the total score. The most suitable city concept will be ranked based on the highest score. An example of the model is shown in Table 2.

The type of city will determine the composition and location of components such as residential, industrial, offices and others. An in-depth interview is conducted with three critical stakeholders which are related to the project development - railways, insurance companies and government institutions. This aims to validate the research concept and to generate substantial input for project improvement.

\section{RESULTS AND DISCUSSION}

\subsection{Decision Matrix}

The analysis compared each of the five identified indicators. For instance, A, representing the potential sector, compared to $\mathbf{B}$, representing development cost. The results show that development cost has a high impact, equal to three, for the potential sector. Thus it is input as $\mathrm{B}(3)$. All indicators are compared to each other to generate their relative degree of importance. According to the analysis, economic growth is the highest indicator at about $40 \%$. This is followed by development cost (30\%), and population growth (20\%). Potential sector and period of growth share similar contributions of about $5 \%$. The summary can be seen in Table 3.

Table 3 Ranking of indicators for Walini

\begin{tabular}{|c|c|c|c|c|c|c|c|}
\hline & B & C & D & $\mathbf{E}$ & Score & Percentage & Description \\
\hline \multirow[t]{6}{*}{ A } & B 3 & $\begin{array}{ll}\mathrm{C} & 1 \\
\end{array}$ & D 3 & E 2 & 1 & $5 \%$ & $\mathrm{~A}$ \\
\hline & B & $\begin{array}{ll}\text { B } & 1\end{array}$ & D 1 & B 2 & 6 & $30 \%$ & B \\
\hline & & $\mathbf{C}$ & D 2 & E 2 & 1 & $5 \%$ & $\mathrm{C}$ \\
\hline & & & D & D 2 & 8 & $40 \%$ & $\mathrm{D}$ \\
\hline & & & & $\mathbf{E}$ & 4 & $20 \%$ & $\mathrm{E}$ \\
\hline & & & & & 20 & $100 \%$ & \\
\hline
\end{tabular}

Legend; A : potential sector; B : development cost; C : period of growth; $\mathrm{D}$ : economic growth; $\mathrm{E}$ : population growth 
Ranking of the indicators from Table 3 is used for the scores in Table 4. Overall, the agriculture city produces the highest indicator for the potential sector at $72.73 \%$ followed by the business city and the IT-based city. It also produces the highest score regarding development cost and period of development. For economic development, the IT-based city is the highest at 58.33\%, followed by the centralized-government city and the business city. Furthermore, population growth relates most strongly to the business city, then the IT-based city, and the centralizedgovernment city respectively.

Despite showing the highest score for three indicators, the agriculture city is ranked as the second highest concept for implementation, because the three highest scores only contribute $40 \%$ of the total score of indicators and two other components generate an insignificant result. Therefore, it is suggested that Walini should applying the concept of the IT-based city. The summary of the decision matrix can be seen in Table 4 .

Table 4 Decision matrix of the project

\begin{tabular}{|c|c|c|c|c|c|c|c|}
\hline Indicator & $\mathrm{A}$ & B & $\mathrm{C}$ & $\mathrm{D}$ & $\mathrm{E}$ & & \\
\hline Score & $5 \%$ & $30 \%$ & $5 \%$ & $40 \%$ & $20 \%$ & & \\
\hline \multicolumn{6}{|c|}{ City type alternatives } & Total Score & Rank \\
\hline \multirow{2}{*}{$\begin{array}{l}\text { Centralized- } \\
\text { government city }\end{array}$} & $0 \%$ & $23.08 \%$ & $38.46 \%$ & $25 \%$ & $18.18 \%$ & \multirow{2}{*}{$22.48 \%$} & \multirow{2}{*}{3} \\
\hline & $0 \%$ & $6.92 \%$ & $1.92 \%$ & $10 \%$ & $3.64 \%$ & & \\
\hline \multirow{2}{*}{ Business city } & $18.18 \%$ & $7.69 \%$ & $15.38 \%$ & $16.67 \%$ & $45.45 \%$ & \multirow{2}{*}{$19.74 \%$} & \multirow{2}{*}{4} \\
\hline & $0.91 \%$ & $2.31 \%$ & $0.77 \%$ & $6.67 \%$ & $9.09 \%$ & & \\
\hline \multirow{2}{*}{ Agriculture city } & $72.73 \%$ & $69.23 \%$ & $46.15 \%$ & $0.00 \%$ & $0.00 \%$ & \multirow{2}{*}{$26.71 \%$} & \multirow{2}{*}{2} \\
\hline & $3.64 \%$ & $20.77 \%$ & $2.31 \%$ & $0.00 \%$ & $0.00 \%$ & & \\
\hline \multirow{2}{*}{ IT-Based city } & $9.09 \%$ & $0.00 \%$ & $0.00 \%$ & $58.33 \%$ & $36.36 \%$ & \multirow{2}{*}{$31.06 \%$} & \multirow{2}{*}{1} \\
\hline & $0.45 \%$ & $0.00 \%$ & $0.00 \%$ & $23.33 \%$ & $7.27 \%$ & & \\
\hline
\end{tabular}

Legend; A : potential sector; B : development cost; C : period of growth; D : economic growth; E : population growth

\subsection{The Concept for New Walini}

As the concept is for an IT-based city, high-tech industry is allocated space inside the city in the initial planning. Overall, there are six areas of development for New Walini from residential, commercial, and offices, to high-tech industry, research universities, and open space. The city concept allocates $55.95 \%$ of the land for buildings with the remainder for open space. Of the building area, residential requires $36.88 \%$, offices need $5.53 \%$, commercial $8.85 \%$, high-tech industry $4.69 \%$ and research university $9 \%$.

Residential building areas of 415 ha are spread across the area of development. These are located near retail and offices and use a medium-rise building concept. Furthermore, residential areas on the west and east of the city will use a cluster concept and low-rise building. The residential area will be provided with public facilities such as a hospital, worship center, shopping area and others. The residential and offices concept is visualized in Figures 1 and 2.

The commercial area is located near Walini rail station at the southern part of Cikalong Wetan. It consists of a shopping center, hotels, and low-rise retail. The concept is also supported by public facilities such as schools, hospitals, and government offices. The concept can be seen in Figure 3. 


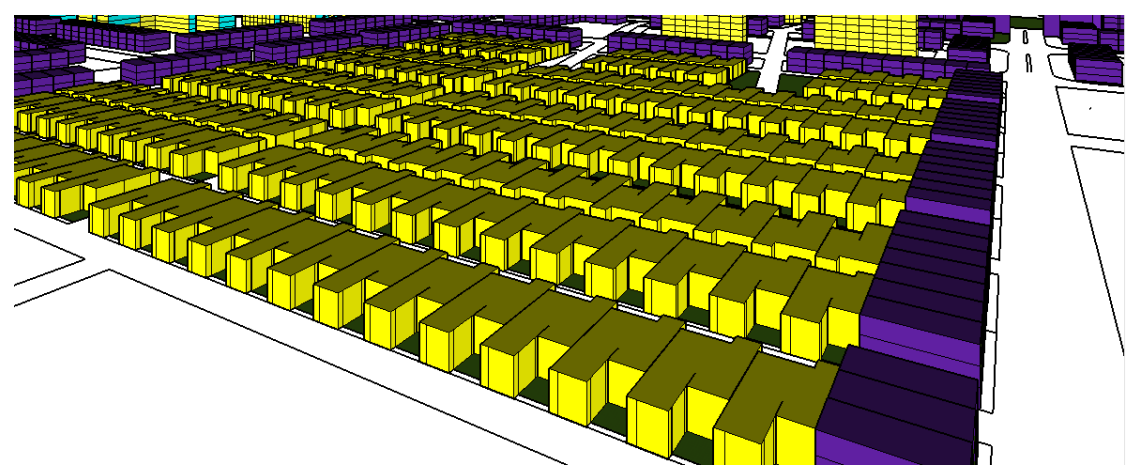

Figure 1 Residential area model

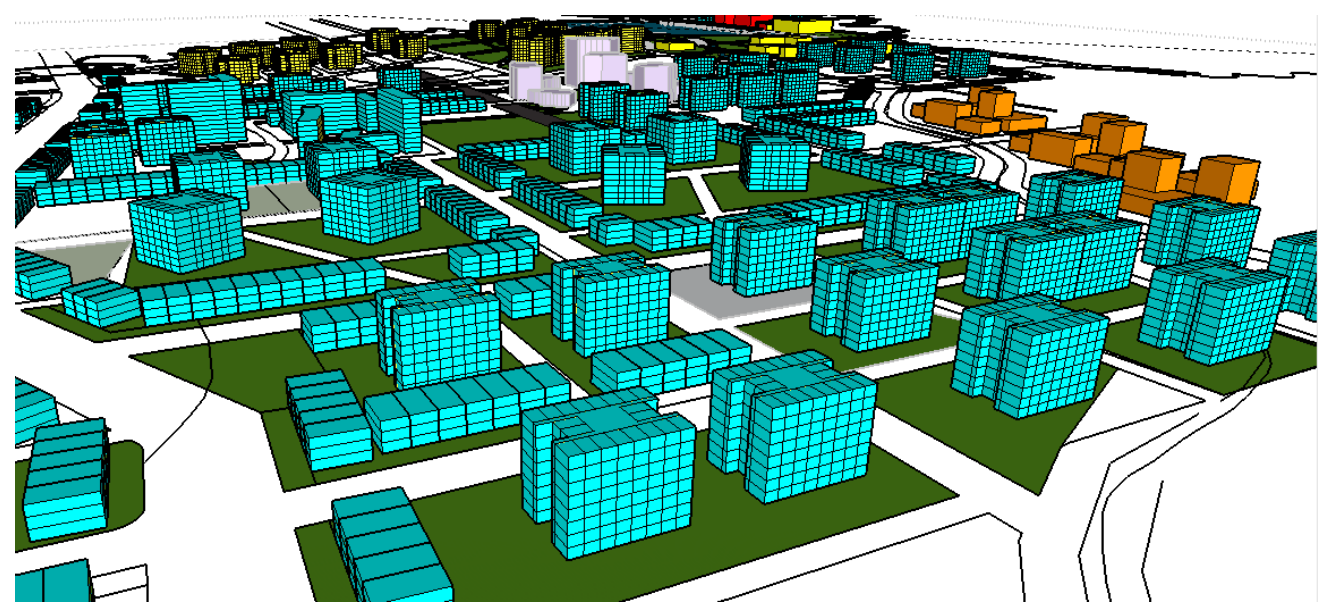

Figure 2 Offices model

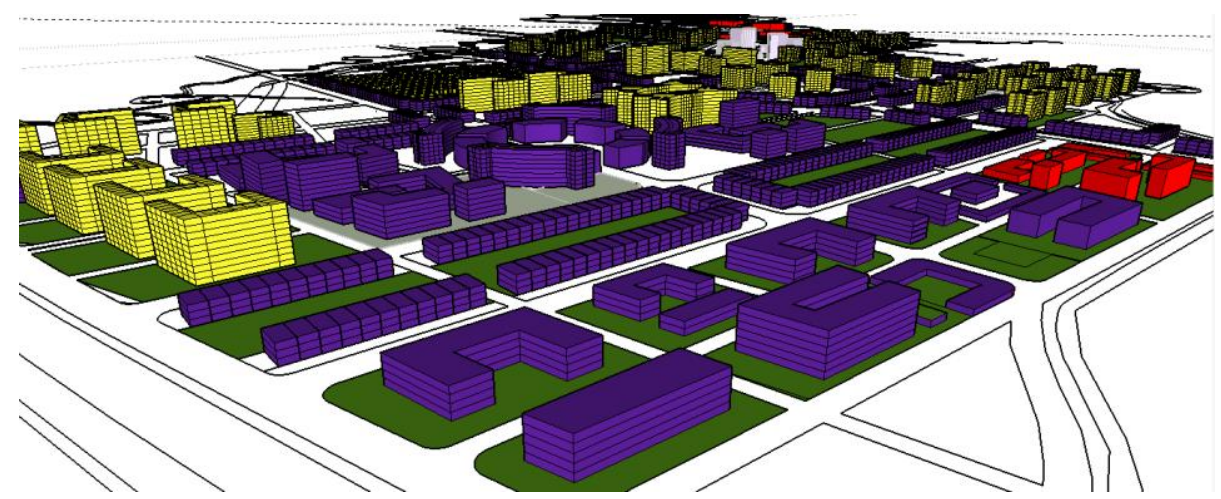

Figure 3 Commercial and public facilities model

Moreover, a research and development $(R \& D)$ area is located in the eastern part of the city. It will be support by offices, high-tech industries, a research university, and residential building. The zoning locates all $\mathrm{R} \& \mathrm{D}$ in one area to accommodate putting the research output delivered from academic-based researchers into practice in industrial settings. Zoning of the area can be seen in Figure 4.

The city is supported by local infrastructure transportation by developing the railway, a new station, and revitalizing Rendeh Station. The railway track will connect to the existing commuter line for cost saving and is estimated to be about $10 \mathrm{~km}$ in length. In terms of road infrastructure, the city has a stretch of highway from Purwakarta-Cikalong Wetan-Bandung which is in excellent condition. 


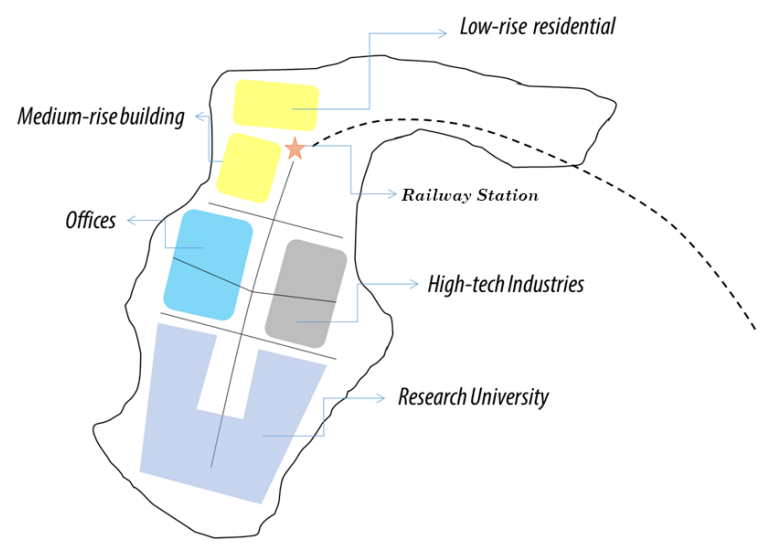

Figure 4 Detail of the zoning of the R\&D area

The selected routes that require renewals and repairs are located in the Rendeh Station area and the Cipendeuy district. The overall proposed concept for Walini can be seen in Figure 5.

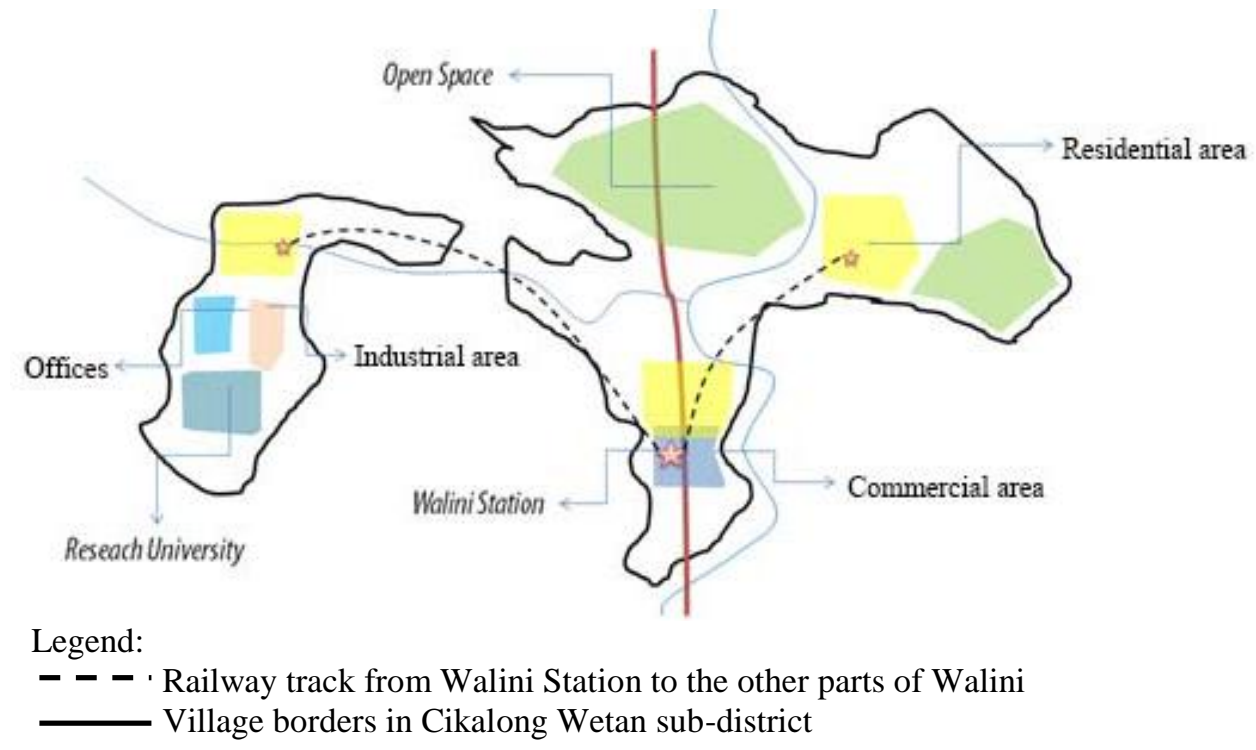

Figure 5 Map of new city development in the Walini Area

In-depth interviews with related stakeholders show that the concept has potential attractions both for regional development and the high-speed train project. Respondents from both railway and insurance companies argue that offices and high-tech industry will attract start-up and established companies not only from Bandung region but also from the capital city area. Such development may increase traffic volume in terms of passenger demand, and provide new space at competitive cost for office investment. However, ease of accessibility and high-speed internet access should be taken into account as the primary considerations before transforming the concept into reality.

A respondent from a government institution added that R\&D should be the core of an IT-based city and should have a significant allocation of land. The respondent also suggested further evaluation of the cost of development. As the government has limited funds, encouraging private and other reliable entities to invest in Walini's development is preferred. Collaboration and close communication among related parties should be encouraged to achieve the proposed concept for the new city of Walini. 


\section{CONCLUSION}

The presence of infrastructure is related to the significant development of a region and contributes to the economic activities of the population. As the construction of the JakartaBandung high-speed railway progresses, the Walini area has the potential to improve its regional competitiveness by attracting new business to the area and generating more revenues from the railway project.

Many cities across the world have different styles for developing their areas. From many types of cities, four were selected as offering the best potential for the new city of Walini. The types selected were centralized-government city, business city, agriculture city, and IT-based city. An IT-based city concept was chosen for Walini after considering the potential sector, development cost, period of development, economic growth, and population growth.

The city will have six components: residential, commercial, offices, high-tech industry, research universities and open space. An R\&D area will be developed in the western part of Walini, supported by high-tech industry and educational institutions. Residential areas will be constructed near commercial and office areas. Supporting infrastructures, such as a station, revitalized existing Rendeh Station and new railway track that connects residential and business areas, will be built to support people's mobility and as a means to provide alternative transportation for users.

\section{ACKNOWLEDGEMENT}

This research is supported by a grant from Ministry of Research, Technology and Higher Education, Republic of Indonesia. Contract number: 2754/UN2.R3.1/HKP05.00/2017

\section{REFERENCES}

Berawi, M.A., Susantono, B., 2012. Developing Conceptual Design of Mega Infrastructure Project: Creating Innovation and Added Value. Value World, Volume 35(1), pp. 12-20

Berawi, M.A., Woodhead, R.M., 2008. Stimulating Innovation using Function Models: Adding Product Value. Value World, Volume 31(2), pp. 4-7

Berawi, M.A, Berawi, A., Prajitno, I., Nahry, N., Miraj, P., Abdurachman, Y., Tobing, E., Ivan, A., 2015. Developing Conceptual Design of High-speed Railways using Value Engineering Method: Creating Optimum Project Benefits. International Journal of Technology, Volume 6(4), pp. 670-679

Berawi, M.A., 2017. The Role of Technology in Achieving Sustainable Development Goals. International Journal of Technology, Volume 8(3), pp. 362-365

Birch, D.L., 1971. Toward a Stage Theory of Urban Growth. Journal of the American Institute of Planners, Volume 37(2), pp. 78-87

Department of Statistics Malaysia, 2015. GDP by State, 2010-2014. Malaysia: Department of Statistics Malaysia

Department of Statistics Singapore, 2015. Singapore in Figure. Singapore: Department of Statistics Singapore

Etzkowitz, H., 2011. The Triple Helix: Science, Technology, and the Entrepreneurial Spirit. Journal of Knowledge-based Innovation in China, Volume 3(2), pp. 76-90

Friedmann, J., 1986. The World City Hypothesis. Development and Change, Volume 17(1), pp. 69-83

Karim, S.B.A., Rahman, H.A., Berawi, M.A., Jaapar, A., 2007. A Review on the Issues and Strategies of Stakeholder Management in the Construction Industry. In: Meeting and Conference on Management in Construction and Researchers Association (MICRA) 
Komarova, V.N., Zjablova, O.V., Denmukhametov, R.R., 2014. An Infrastructure Factor in Regional Competitiveness. Mediterranean Journal of Social Sciences, Volume 5(18), pp. 355-359

Leigh, N.G., Blakely, E.J., 2013. Planning Local Economic Development: Theory and Practice. SAGE Publications, Incorporated

Monastiriotis, V., 2014. Regional Growth and National Development: Transition in Central and Eastern Europe and the Regional Kuznets Curve in the East and the West. Spatial Economic Analysis, Volume 9(2), pp. 142-161

Nijkamp, P., 2016. Spatial Dynamics, Innovation and Infrastructure: A Long Wave View of Regional Development in Developing and Developed Countries. Technology Transfer in the Developing Countries, pp. 76-93

North, D.C., 1955. Location Theory and Regional Economic Growth. Journal of Political Economy, Volume 63(3), pp. 243-258

Ooms, W., Werker, C., Caniëls, M.C., Van Den Bosch, H., 2015. Research Orientation and Agglomeration: Can Every Region Become a Silicon Valley. Technovation, Volume 4546, pp. 78-92

Pike, A., Rodríguez-Pose, A., Tomaney, J., 2016. Shifting Horizons in Local and Regional Development. Regional Studies, Volume 51(1), pp. 1-12

Statistics New Zealand, 2015. Regional Gross Domestic Product: Year Ended March 2014. Auckland

Woodhead, R.M., Berawi, M.A., 2008. An Alternative Theory of Idea Generation. International Journal of Management Practice, Volume 3(1), pp. 1-19 